\title{
Biological Perspectives
}

\section{Role of the Peroxynitrite-Poly(ADP-Ribose) Polymerase Pathway in Human Disease}

\author{
Pal Pacher* and Csaba Szabo ${ }^{\dagger}$ \\ From the Section on Oxidative Stress Tissue Injury," Laboratory \\ of Physiological Studies, National Institute on Alcohol Abuse and \\ Alcoholism, National Institutes of Health, Bethesda Maryland; \\ and the Department of Surgery, ${ }^{\dagger}$ University of Medicine and \\ Dentistry, New Jersey, New Jersey Medical School, Newark, \\ New Jersey
}

Throughout the last 2 decades, experimental evidence from in vitro studies and preclinical models of disease has demonstrated that reactive oxygen and nitrogen species, including the reactive oxidant peroxynitrite, are generated in parenchymal, endothelial, and infiltrating inflammatory cells during stroke, myocardial and other forms of reperfusion injury, myocardial hypertrophy and heart failure, cardiomyopathies, circulatory shock, cardiovascular aging, atherosclerosis and vascular remodeling after injury, diabetic complications, and neurodegenerative disorders. Peroxynitrite and other reactive species induce oxidative DNA damage and consequent activation of the nuclear enzyme poly(ADP-ribose) polymerase 1 (PARP-1), the most abundant isoform of the PARP enzyme family. PARP overactivation depletes its substrate $\mathrm{NAD}^{+}$, slowing the rate of glycolysis, electron transport, and ATP formation, eventually leading to functional impairment or death of cells, as well as up-regulation of various proinflammatory pathways. In related animal models of disease, peroxynitrite neutralization or pharmacological inhibition of PARP provides significant therapeutic benefits. Therefore, novel antioxidants and PARP inhibitors have entered clinical development for the experimental therapy of various cardiovascular and other diseases. This review focuses on the human data available on the pathophysiological relevance of the peroxynitritePARP pathway in a wide range of disparate diseases, ranging from myocardial ischemia/reperfusion injury, myocarditis, heart failure, circulatory shock, and diabetic complications to atherosclerosis, arthritis, colitis, and neurodegenerative disorders. (Am J Pathol 2008, 173:2-13; DOI: 10.2353/ajpath.2008.080019)
The nuclear enzyme poly(ADP-ribose) polymerase 1, a highly conserved protein of $116 \mathrm{kDa}$, is the most abundant isoform of the PARP enzyme family. The structure and the function of PARP-1 has been a subject of a number of recent reviews. ${ }^{1-3}$ Poly(ADP-ribosyl)ation has been implicated in the regulation of multiple physiological cellular functions such as DNA repair, gene transcription, cell cycle progression, cell death, chromatin function, and genomic stability. ${ }^{4}$ Because PARP becomes activated in response to DNA breaks, the nature of the various endogenous species capable of inducing DNA strand breaks, and thereby activating PARP, in various disease conditions has become of crucial interest. Peroxynitrite (a reactive nitrogen species formed from the diffusion-limited reaction of nitric oxide and superoxide anion) has been identified as a pathophysiologically relevant trigger of PARP activation (Figure 1). 1,2 Peroxynitrite can also induce pathophysiological alterations independently from PARP as well. These alterations are multiple, and include protein modifications (of which the most studied is tyrosine nitration), DNA modifications, alterations in cellular signal transduction pathways, leading to changes in inflammatory responses and promotion of cell death via apoptotic and necrotic routes (Figure 1). ${ }^{5,6}$ It has been suggested that there is an additive or synergistic relationship between the PARP-dependent and the PARP-independent pathophysiological actions. ${ }^{6-8}$ From a pathophysiological standpoint, PARP activation can contribute to the development of disease via two main mechanisms: by driving the cell into an energetic

Supported by the National Institutes of Health (Intramural Research Program of the National Institute on Alcohol Abuse and Alcoholism grant to P.P. and grant R01 GM060915 to C.S.).

Accepted for publication March 17, 2008.

Disclosures: C.S. is one of the founders of Inotek Inc., which is developing PARP inhibitors. C.S. was Chief Scientific Officer from 1998-2005 and still owns stock in Inotek.

Address reprint requests to Pal Pacher, M.D., Ph.D., F.A.P.S., F.A.H.A., Section on Oxidative Stress and Tissue Injury, Laboratory of Physiologic Studies, National Institutes of Health/NIAAA, 5625 Fishers Lane, MSC9413, Bethesda, MD 20892-9413. E-mail: pacher@mail.nih.gov; or Csaba Szabo, M.D., Ph.D., D.Sci., Department of Surgery, UMDNJ-New Jersey Medical School, 185 South Orange Ave., Newark, NJ 07103. E-mail: szabocsaba@aol.com. 


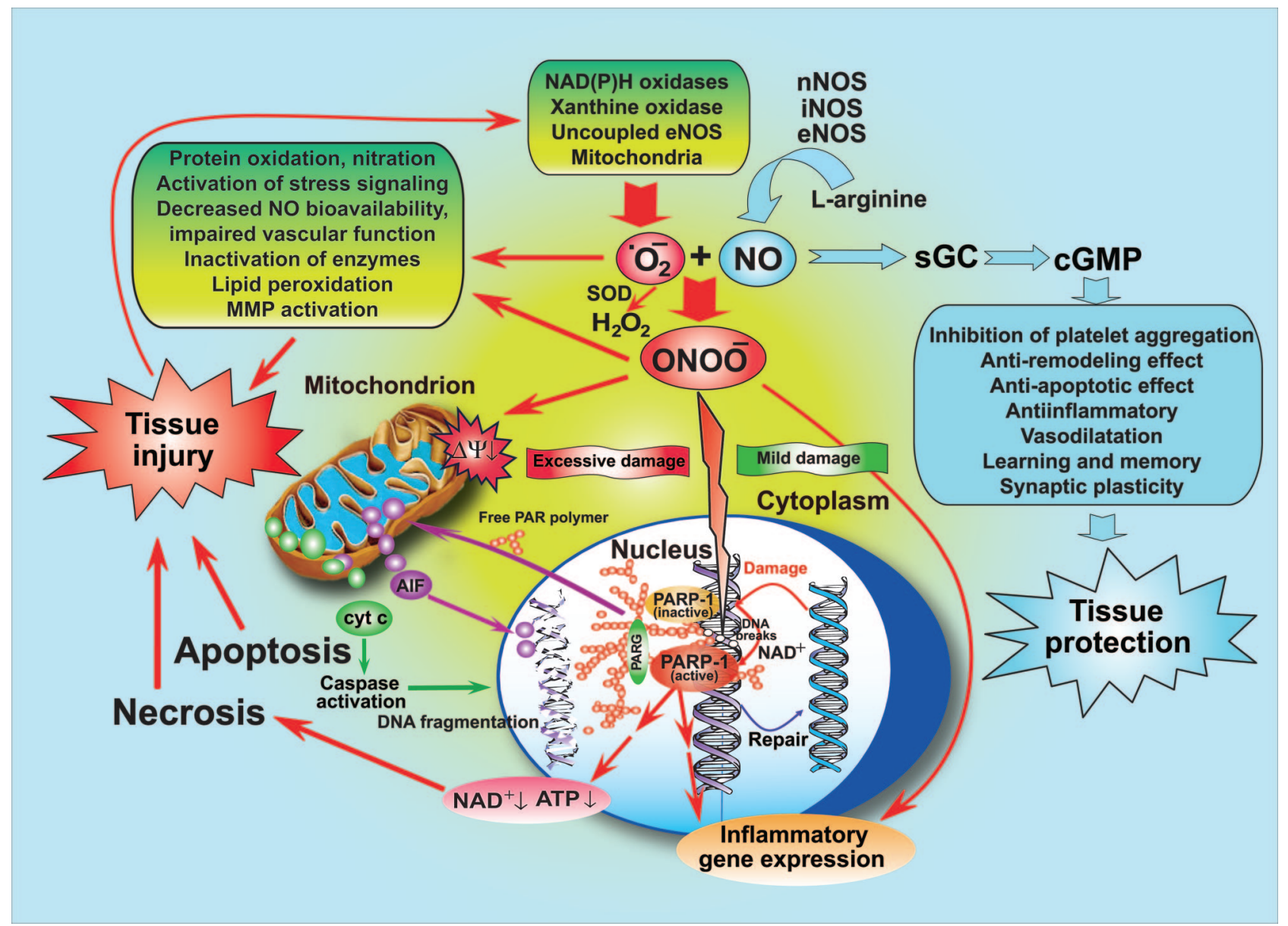

Figure 1. The nitric oxide-peroxynitrite-PARP pathway in health and disease. Nitric oxide (NO) activates the soluble guanylate cyclase (sGC)-cyclic guanosine$3^{\prime}, 5^{\prime}$-monophosphate (cGMP) signal transduction pathway and mediates various physiological/beneficial effects including synaptic plasticity; vasodilation; inhibition of platelet aggregation; anti-inflammatory, anti-remodeling, and anti-apoptotic effects; just mentioning a few. Under pathophysiological conditions (eg, stroke, myocardial infarction, chronic heart failure, diabetes, circulatory shock, chronic inflammatory diseases, cancer, and neurodegenerative disorders, and so forth), nitric oxide and superoxide $\left(\mathrm{O}_{2}{ }^{-}\right)$react to form peroxynitrite $\left(\mathrm{ONOO}^{-}\right)$that induces cell damage via lipid peroxidation, inactivation of enzymes and other proteins by oxidation and nitration, and also activation of stress signaling, matrix metalloproteinases (MMPs) among others. Mitochondrial enzymes are particularly vulnerable to attacks by peroxynitrite, leading to reduced ATP formation and induction of mitochondrial permeability transition by opening of the permeability transition pore (PTP), which dissipates the mitochondrial membrane potential $(\Delta \Psi)$. These events result in cessation of electron transport and ATP formation, mitochondrial swelling, and permeabilization of the outer mitochondrial membrane, allowing the efflux of several proapoptotic molecules, including cytochrome $c$ and apoptosis-inducing factor (AIF). In turn, cytochrome $c$ and AIF activate a series of downstream effectors that mediate caspase-dependent and -independent apoptotic death pathways. In addition to its damaging effects on mitochondria, peroxynitrite, in concert with other oxidants, causes oxidative injury to DNA, resulting in DNA strand breakage which in turn activates the nuclear enzyme poly(ADP-ribose) polymerase (PARP-1). Activated PARP-1 consumes NAD to build up poly(ADP-ribose) polymers (PAR), which are themselves rapidly metabolized by the activity of poly(ADP-ribose) glycohydrolase (PARG). Some free PAR may exit the nucleus and travel to the mitochondria, where they amplify the mitochondrial efflux of AIF (nuclear to mitochondria cross talk). Depending on the severity of the initial damage by peroxynitrite and other oxidants, the injured cell may either recover or die. In the latter case, the cell may be executed by apoptosis in case of moderate mitochondrial PTP opening and PARP-1 activation with preservation of cellular ATP, or by necrosis in case of widespread PTP opening and PARP-1 overactivation, leading to massive NAD consumption and collapse of cellular ATP. Overactivated PARP-1 also facilitates the expression of a variety of inflammatory genes leading to increased inflammation and associated tissue injury.

deficit and a state of dysfunction and by catalyzing the activation of proinflammatory pathways. Regarding the former pathway, PARP-1 functions as a DNA damage sensor and signaling molecule, binding to both singleand double-stranded DNA breaks. On binding to damaged DNA, PARP-1 forms homodimers and catalyzes the cleavage of $\mathrm{NAD}^{+}$into nicotinamide and ADP-ribose to form long branches of ADP-ribose polymers on target proteins such as histones and PARP-1 itself. This process results in cellular energetic depletion, mitochondrial dysfunction, and ultimately necrosis. ${ }^{1,2}$ As for the latter pathway, numerous transcription factors, DNA replication factors, and signaling molecules have also been shown to become poly(ADP-ribosylated) by PARP-1, but a PARP- mediated activation of the pluripotent transcription factor nuclear factor $-\kappa \mathrm{B}(\mathrm{NF}-\kappa \mathrm{B})$ appears to be of crucial importance. $^{2,9}$ Importantly, numerous recent studies have suggested that PARP-1 activity can be modulated by several endogenous factors, and PARP-1 can also modulate important signaling pathways (Figure 2). ${ }^{8}$

Multiple lines of studies demonstrate that neutralization of peroxynitrite and/or pharmacological inhibition or genetic inactivation of PARP is therapeutically effective in a wide range of cardiovascular, inflammatory, vascular, and neurodegenerative diseases, by protecting against cell death as well as by down-regulating multiple inflammatory pathways. ${ }^{2,5,6}$ The main body of evidence on the role of peroxynitrite and PARP in the development of 


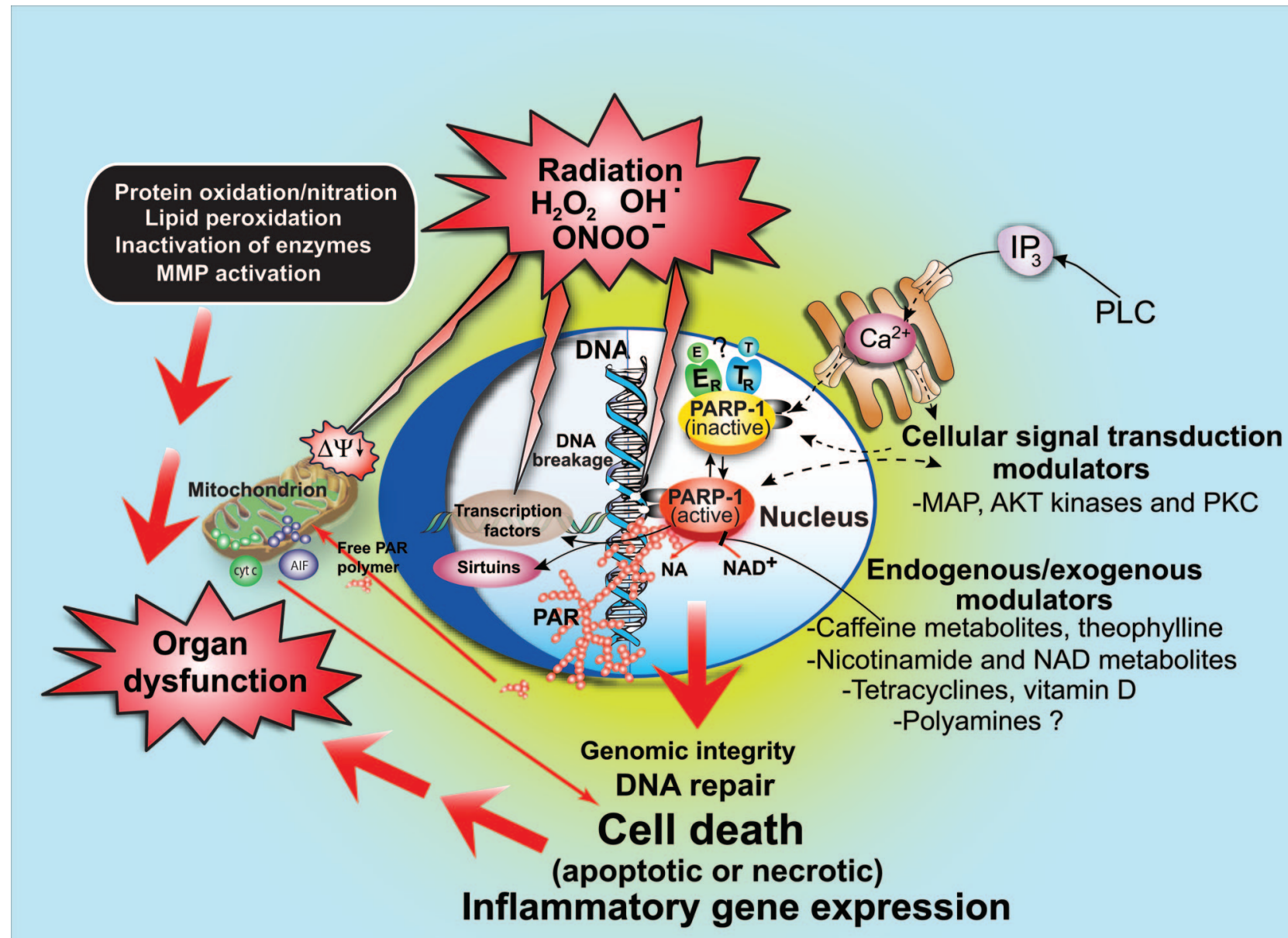

Figure 2. Exogenous/endogenous, regulators/modulators of PARP activity. Various endogenous factors can influence PARP activity either by forming a complex with PARP or inhibiting the binding of its substrate $\mathrm{NAD}^{+}$to the active site of the enzyme. Such examples may include estrogen (E), thyroid hormones (T), nicotinamide (NA), NAD ${ }^{+}$metabolites, and vitamin D. PARP activity can also be modulated by various kinases by phosphorylation (eg, MAP kinases and PKC), and PARP can modulate kinase (eg, AKT) activity. Different exogenous factors (eg, caffeine and its endogenously formed metabolites, theophylline, and tetracycline antibiotics) may also modulate PARP activity.

disease is based on in vitro studies (including studies in human primary cells and cell lines), as well as on various animal models of disease, and has been reviewed in multiple specialized review articles. ${ }^{3,8,10-18}$ The current review focuses on the evidence accumulating on the pathophysiological pathways associated with the production of peroxynitrite and the activation of PARP specifically in human disease (see also Table 1).

The connection between these two pathophysiological pathways is close and multiple, as supported by in vitro data, as well as preclinical animal studies using various pharmacological inhibitors. The pathological activation of PARP requires the development of DNA single-strand breaks in vivo. ${ }^{75}$ In theory, breaks in the DNA can be brought about by a variety of oxidant and free radical species, including hydroxyl radical and peroxynitrite (but not by superoxide or nitric oxide). From a variety of studies, however, it is clear (as discussed in Virag and Szabo ${ }^{1}$ ), that peroxynitrite is the key pathophysiological species that can trigger such DNA injury in vivo. Peroxynitrite is formed by the rapid, diffusion-controlled reaction of $\mathrm{NO}$ and superoxide, with superoxide being the concentration-limiting step in most disease conditions., ${ }^{5,6}$ Peroxynitrite (as opposed to hydroxyl radical, which does not travel significant distances), can cross cell membranes, enter the nucleus, and trigger breaks in the strands of the DNA. ${ }^{1,5,6}$ Currently, no other species is known with the capacity of both having a long enough half-life to travel within and between cells and having the ability to break the DNA. ${ }^{6}$ In vitro studies clearly demonstrate that exogenously applied or endogenously produced peroxynitrite induces DNA strand breakage and PARP activation, and peroxynitrite-induced cell death can be attenuated by pharmacological inhibition of PARP or by genetic inactivation of PARP-1. ${ }^{76-78}$ The connection between peroxynitrite production and PARP activation in various disease conditions in vivo is also supported by a variety of in vivo studies showing the formation of peroxynitrite (usually by its footprint, nitrotyrosine) and the development of DNA strand breaks and PARP activation in closely overlapping organs and tissues in a variety of diseases (see following sections). Furthermore, there are 
Table 1. Evidence for Peroxynitrite Formation and PARP Activation in Selected Human Diseases

\begin{tabular}{|c|c|}
\hline Disease & Human evidence for peroxynitrite formation \\
\hline $\begin{array}{l}\text { Myocardial } \\
\text { infarction, bypass } \\
\text { surgery, cardiac } \\
\text { allograft rejection }\end{array}$ & $\begin{array}{l}\text { Increased oxidative stress, NO breakdown products, } \\
\text { and nitrotyrosine in the serum and/or in myocardial } \\
\text { biopsy specimens before and at the end of } \\
\text { cardiopulmonary bypass, cardiac allograft rejection, } \\
\text { and in patients with cardiogenic shock after acute } \\
\text { myocardial infarction. }{ }^{19-26}\end{array}$ \\
\hline Circulatory shock & $\begin{array}{l}\text { In chronic renal failure patients with septic shock there } \\
\text { is an increase in plasma nitrotyrosine. Plasma } \\
\text { nitrotyrosine levels correlate with the severity of } \\
\text { septic shock. Specific myocardial and skeletal } \\
\text { muscle proteins show nitration in human sepsis } \\
\text { (including inducible NO synthase). }{ }^{6,29,30}\end{array}$ \\
\hline $\begin{array}{l}\text { Chronic heart } \\
\text { failure }\end{array}$ & $\begin{array}{l}\text { SERCA nitration is increased in human heart failure. } \\
\text { Cardiomyocyte and skeletal muscle tyrosine nitratior } \\
\text { is increased in patients with heart failure. } \\
\text { Overexpression of inducible NO synthase in human } \\
\text { myocytes induces depression of cardiac contractilit } \\
\text { via a mechanism that probably involves } \\
\text { peroxynitrite. }\end{array}$ \\
\hline $\begin{array}{l}\text { Stroke, brain } \\
\text { ischemia, brain } \\
\text { trauma }\end{array}$ & $\begin{array}{l}\text { Increased nitrotyrosine staining of brain tissue in } \\
\text { asphyxiated neonates, and elevated plasma } \\
\text { nitrotyrosine levels in patients with acute ischemic } \\
\text { stroke compared to controls. }{ }^{39-41}\end{array}$ \\
\hline $\begin{array}{l}\text { Neuroinflammatory } \\
\text { diseases }\end{array}$ & $\begin{array}{l}\text { Increased oxidative stress and increased NO } \\
\text { breakdown products in the cerebrospinal fluid of } \\
\text { multiple sclerosis patients. Increased tyrosine } \\
\text { nitration in post-mortem analysis of CNS lesions } \\
\text { from multiple sclerosis patients. }{ }^{6,44}\end{array}$ \\
\hline $\begin{array}{l}\text { Neurodegenerative } \\
\text { diseases }\end{array}$ & $\begin{array}{l}\text { Human evidence for the nitration and oxidative } \\
\text { dimerization of tau protein, tyrosine hydroxylase, } \\
\text { and } \alpha \text {-synuclein in Alzheimer's disease, Parkinson's } \\
\text { disease, and ALS. }{ }^{6,44}\end{array}$ \\
\hline $\begin{array}{l}\text { Local inflammatory } \\
\text { diseases } \\
\text { (arthritis, colitis) }\end{array}$ & $\begin{array}{l}\text { Increased oxidative stress, increased NO breakdown } \\
\text { products, and elevated tyrosine nitration in synovial } \\
\text { fluid from arthritic patients. Increased tyrosine } \\
\text { nitration in colonic biopsies of colitic patients. }\end{array}$ \\
\hline
\end{tabular}

Vascular diseases including diabetic complications

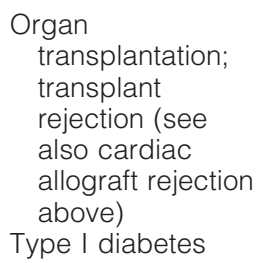

Pulmonary diseases
Increased oxidative stress, increased NO breakdown products, and elevated tyrosine nitration in serum and vascular/myocardial samples from patients with hypertension, atherosclerosis, and diabetic vascular disease. Kidneys of patients with diabetic nephropathy and microvessels of diabetic patients show evidence of tyrosine nitration. There is marked placental tyrosine nitration in diabetes. Circulating leukocytes also show signs of tyrosine nitration.,5,54-63

Human evidence for nitrated MnSOD in kidney transplants. ${ }^{5,6}$

Diabetic islets show elevated levels of 3-nitrotyrosine. Human pancreatic $\beta$-cells are sensitive to the toxic effect of peroxynitrite. The presence of AEOL-10150 during human islet preservation improves islet function and preserves pancreatic islet mass. ${ }^{5,6}$

Elevated levels of nitrotyrosine have been detected in the serum, bronchoalveolar lavage fluid, and lung sections of patients with acute lung injury [eg, the acute respiratory distress syndrome (ARDS)], and antibodies against these nitrated proteins. ${ }^{69-72}$ Elevated serum nitrotyrosine levels were associated with vascular damage to the lung in patients with systemic sclerosis. ${ }^{73}$
Human evidence for PARP activation

PARP activation in circulating leukocytes in patients with myocardial infarction and therapeutic revascularization. ${ }^{27,28}$

In myocardial sections of patients with circulatory shock, significant PARP activation is observed. The degree of PARP activation shows a close correlation with the degree of myocardial dysfunction. ${ }^{31}$

Poly(ADP-ribosyl)ation in human heart samples in end-stage heart failure and in heart failure followed by left ventricular heart assist device implantation. ${ }^{35-38}$

Activation of PARP in brain sections from patients dying from stroke, brain ischemia attributable to cardiac arrest, as well as in patients with brain trauma. ${ }^{42,43}$

No human evidence so far

Poly(ADP-ribosyl)ation in brain sections from patients with Alzheimer's disease, Parkinson's disease, and ALS. ${ }^{45-48}$

Autoantibodies against PARP in arthritis, SLE, and other autoimmune diseases. Preliminary evidence for increased poly(ADP-ribosyl)ation in biopsies from patients with colitis. Poly(ADPribosyl)ation patterns in human inflamed tissues have not yet been studied in detail. ${ }^{49-53}$

Activation of PARP in human atherosclerotic plaques, in microvessels, and lymphocytes of type 2 diabetic patients. Treatment with angiotensin-II receptor blocker valsartan improves the microvascular function of type 2 diabetic patients, and decreases microvascular PARP activity. ${ }^{13,18,57,64-66}$

Increased expression of PARP-1 in transplanted kidneys correlates with worsened outcome after transplantation. ${ }^{67,68}$

No human evidence so far

Increased poly(ADP-ribosyl)ation in peripheral blood lymphocytes from patients with chronic obstructive pulmonary disease. ${ }^{74}$ 
multiple published animal studies demonstrating that pharmacological neutralization of peroxynitrite formation (by peroxynitrite decomposition catalysts or by various antioxidants inhibiting the formation or reactions of its precursors superoxide and NO) is associated with a reduced degree of PARP activation. ${ }^{79-87}$ These observations support the view that peroxynitrite formation and PARP activation are closely connected in various pathophysiological conditions. Obviously, peroxynitrite can exert PARP-independent pathophysiological actions as well ${ }^{6}$-these effects almost certainly contribute to cell and tissue damage in an additive or synergistic manner with the pathways that involve PARP.

In the following sections we discuss the main cardiovascular, inflammatory, and neurodegenerative diseases in which the reactive oxidant species/PARP relationship has been well established. Although PARP inhibitors have also gained clinical relevance in the context of cancer, in this condition endogenous reactive species do not appear to play a role as an activator of PARP. Instead, PARP inhibition is typically used to prevent the repair of DNA when given in combination of DNA-damaging anticancer drugs. The current review will not cover this separate area, since it has been a subject of multiple recent reviews. ${ }^{88-91}$

\section{Peroxynitrite Formation and PARP Activation in Human Hearts}

There is accumulating evidence (discussed below) in support of the role of endogenous peroxynitrite generation in human myocardium during reperfusion injury, human transplant coronary artery disease, heart failure, viral myocarditis, and sepsis. Ischemic-reperfusion injury is the primary cause of tissue damage occurring in conditions such as stroke, myocardial infarction, cardiopulmonary bypass, aortic reconstructive surgery, organ transplantation, and a pivotal mechanism of end-organ damage complicating the course of circulatory shock. The burst of reactive oxygen species (superoxide anion, hydrogen peroxide, and hydroxyl radical) derived from multiple sources [eg, NAD(P)H and xanthine oxidases, mitochondria, and uncoupled eNOS] and nitrogen species (eg, peroxynitrite) immediately on reperfusion initiates a chain of deleterious cellular responses ultimately leading to the following effects: coronary endothelial dysfunction; adherence of neutrophils to endothelium, transendothelial migration, and the release of inflammatory mediators; transient impairment of left ventricular systolic function or myocardial stunning; acute diastolic dysfunction; cellular calcium overload; re-energization-induced myocyte hypercontracture; arrhythmia; and cell death. ${ }^{6,92,93}$ Numerous recent human studies have investigated plasma nitrotyrosine levels from coronary sinus effluent and/or arterial blood ${ }^{19,20}$ or myocardial nitrotyrosine immunoreactivity (footprint of peroxynitrite formation and nitrative stress) from left ventricular biopsy specimen ${ }^{21}$ before and at the end of cardiopulmonary bypass. The difference between plasma nitrotyrosine levels from coronary sinus effluent and arterial blood (index of myocardium-derived peroxynitrite generation) peaks at 5 min- utes after reperfusion, and significantly correlated with the peak coronary sinus effluent and arterial blood difference in plasma malondialdehyde concentrations (index of myocardial oxidative stress and lipid peroxidation), as well as with postoperative maximum creatinine kinase level (index of myocardial injury). ${ }^{19}$ The cardioplegiainduced myocardial ischemia/reperfusion has also been associated with increased 9-isoprostane and nitrotyrosine formation and inducible nitric oxide synthase (iNOS) expression, ${ }^{21}$ further supporting the role of both reactive oxygen species and peroxynitrite in mediating the myocardial damage. Increased immunostaining for iNOS and nitrotyrosine have also been observed in left ventricular biopsy specimens of patients with hibernating myocardium (a state of chronic contractile dysfunction present at rest in a territory subtended by a stenosed coronary artery that recovers after revascularization, most likely originated from repetitive episodes of transient ischemia ${ }^{22}$ ), and in human coronary arteries of patients with human transplant coronary artery disease, a major cause of late mortality after cardiac transplantation, ${ }^{24}$ and during cardiac allograft rejection in human hearts. ${ }^{23-25}$

Increased nitrotyrosine immunoreactivity has been found in human biopsy specimens with viral myocarditis and sepsis, suggesting a pathogenetic role of peroxynitrite formation and/or protein nitration in these diseases. ${ }^{29,30} \mathrm{~A}$ correlation between increased nitrotyrosine formation with myofibrillar creatine kinase inhibition has also observed in human atrial appendages from patients with fibrillation, ${ }^{94}$ and increased iNOS protein expression correlated with increased nitrotyrosine formation in myocardial specimens of patients with heart failure. Although iNOS-positive patients are generally characterized by larger left ventricular volume and depressed function, the preserved generation of nitric oxide appears to be associated with higher cardiac work attributable to the preserved Frank-Starling relationship in end-stage heart failure. ${ }^{32}$ Increased nitration of sarcoplasmic reticulum $\mathrm{Ca}^{2+}$-ATPase ${ }^{33}$ and myocardial $\alpha$-actinin ${ }^{34}$ in idiopathic dilated cardiomyopathic human hearts has also been reported, and positive correlation between the time to half-relaxation and the nitrotyrosine/SERCA2a content in myocytes has been observed. ${ }^{33}$ Peroxynitrite may also inhibit sGC and impair the activity of ion channels responsible for the generation of $\mathrm{K}^{+}$and $\mathrm{Ca}^{+}$currents, thereby contributing to development of nitrate tolerance in humans. ${ }^{6}$

As reviewed above, reperfusion injury is associated with the production of reactive oxygen and nitrogen species in the human heart in various diseases. It is not surprising, then, that PARP activation also occurs in the same organ, as shown at first in animal cell culture systems ${ }^{11,18,95}$ and in human myocardial cell lines exposed to various oxidants and free radicals. ${ }^{12}$ As far as the evidence for PARP activation in human hearts goes, early series of studies suggest that PARP in myocytes may be a substrate of caspases (and hence a marker, and possible active contributor) of apoptosis. ${ }^{96}$ However, additional work in myocardial infraction and heart failure indicates that the cleavage of PARP is actually not widespread in diseased human hearts. ${ }^{35}$ At present, only a limited number of human studies have been conducted to investigate whether PARP is activated in hu- 
man cardiomyocytes and endothelial cells during myocardial reperfusion injury or cardiac failure. No evidence for significant PARP activation has been noted in human heart atria during blood cardioplegia and cardiopulmonary bypass. ${ }^{97}$ However, in a study ${ }^{27}$ investigating multiple aspects of human myocardial ischemia/reperfusion-related pathologies by analyzing serum, plasma, and isolated peripheral leukocyte samples from cardiovascular patients with acute ST-segment elevation myocardial infarction and successful primary angioplastic intervention have provided evidence for 1) oxidative/peroxidative imbalance (increased total plasma peroxide concentration and nitrotyrosine production), 2) angioplasty-triggered DNA damage (substantiated by increased levels of serum $8 \mathrm{OHdG}$ ), 3) rapid activation of PARP-1 in circulating human peripheral leukocytes (demonstrated by immunohistochemistry and Western blotting) after revascularization of the occluded coronary artery, and 4) translocation of the AIF from mitochondria to nuclei (which might well be a consequence of PARP activation). These observations further support the theory that recanalization of an occluded blood vessel triggers oxidative/nitrosative stress in humans and demonstrate that local myocardial ischemia/reperfusion triggered by percutaneous interventions in acute myocardial infarction is capable of generating systemic oxidative responses. ${ }^{27}$ Similar findings have been reported in follow-on study in circulating mononuclear cells obtained from patients with myocardial infarction without revascularization. ${ }^{28}$ Inotek (Beverly, MA) is developing the potent PARP inhibitor INO-1001. The first human clinical study with a PARP inhibitor in a cardiovascular indication involved a phase 2 prospective, single-blind, multicenter, dose-escalation study of a single dose of intravenous INO-1001 administered to patients with acute STEMI, who were to be treated with primary percutaneous coronary intervention. INO-1001 induced a tendency to reduce the plasma levels of C-reactive protein and the inflammatory marker interleukin-6, without reducing plasma markers of myocardial injury. No drug-related serious adverse events were observed in the patients receiving drug during the study period. ${ }^{98}$ Although some of these data appear encouraging, additional studies in larger patient population are needed.

There is also evidence for PARP activation in human myocytes during heart failure after left ventricular assist device implantation, ${ }^{35}$ as well as in end-stage cardiac failure ${ }^{36-38}$ and in septic shock. ${ }^{31}$ In the latter condition, a statistically significant positive correlation has been noted between degree of myocardial PARP activation and the degree of myocardial dysfunction, supporting the view that PARP activation is an active contributor to the loss of cardiac contractility in sepsis.

\section{Peroxynitrite Formation and PARP Activation in Diseases of the Central and Peripheral Nervous System}

Peroxynitrite formation and/or protein nitration has been implicated in pathogenesis of stroke, Alzheimer's disease, Parkinson's disease, amyotrophic lateral sclerosis, and multiple sclerosis. ${ }^{6,44}$ Nitrotyrosine immunoreactivity is increased in these disorders in human autopsy samples, and elevated free nitrotyrosine, nitrite, and nitrate levels are detected in the cerebral spinal fluid of patients. 6,44 Once generated in the diseased brain, peroxynitrite may exert its toxic effects via multiple mechanisms, including protein nitration and oxidation, lipid peroxidation, mitochondrial damage, depletion of antioxidant reserves (especially glutathione), activation or inhibition of various signaling pathways, and DNA damage followed by the activation of the nuclear enzyme PARP. 2,6,44

There is extensive evidence obtained from various preclinical models of stroke on the generation and pathophysiological role of endogenous peroxynitrite formation based on the demonstration that nitrotyrosine rapidly accumulates in the brain after transient or permanent ischemia, and the nitrotyrosine accumulation is markedly prevented by strategies blocking nitric oxide or superoxide generation, as well as by treatments aimed at directly scavenging peroxynitrite. ${ }^{5,6}$ Increased nitrotyrosine staining of brain tissue in asphyxiated neonates has been demonstrated, $^{39}$ and plasma nitrotyrosine levels are significantly higher in patients with acute ischemic stroke compared with controls. ${ }^{40,41}$

Increased nitrotyrosine levels have been found in hippocampus, neocortical regions, and cerebrospinal fluid of Alzheimer's disease patients. ${ }^{6}$ Notably, the high levels of 3-NT in cerebrospinal fluid correlates with the decrease in cognitive function in Alzheimer's disease patients. ${ }^{6}$ Nitration of a variety of proteins including synaptophysin, proteins involved in glucose metabolism, cytoskeletal integrity, antioxidant defense, just naming a few, have also been reported in Alzheimer's disease. ${ }^{6}$

Increased nitrotyrosine accumulation has been found in Lewy bodies (a characteristic feature of Parkinson's disease) and polymorphonuclear cells of Parkinson's disease patients. ${ }^{6}$ In the latter the accumulation of nitrotyrosine-containing proteins is accompanied by overexpression of $\mathrm{nNOS}^{6}$ Peroxynitrite may contribute to nitration and inactivation of tyrosine hydroxylase (the rate limiting enzyme in the biosynthesis of dopamine), glutathione reductase, and mitochondrial complex I, thereby contributing to damage of neuronal cells. ${ }^{6,44}$

Increased immunoreactivity for iNOS and nitrotyrosine is also detectable in inflammatory plaques in multiple sclerosis patients together with elevated levels of nitrate and nitrite in cerebrospinal fluid, urine, and serum. ${ }^{6}$ Furthermore, the overall improvement of the inflammatory disease is associated with attenuated iNOS expression in demyelinated plaques from multiple sclerosis patients. ${ }^{6}$ A number of investigators have also found increased tyrosine nitration in human amyotrophic lateral sclerosis patients. ${ }^{6}$

In accordance with the multiple studies demonstrating increased peroxynitrite formation (and increased oxidative and nitrosative stress, in general) in various human central nervous system diseases, there is also evidence for the role of PARP activation in the central nervous system in various forms of human diseases including stroke, ${ }^{43}$ global brain ischemia after cardiac arrest, ${ }^{42}$ 
Alzheimer's disease, ${ }^{45}$ Parkinson's disease, ${ }^{46}$ and amyotrophic lateral sclerosis. ${ }^{47,48}$ In human stroke, it is interesting to note that the pattern of PARP activation is biphasic In the early stage of stroke (up to 24 hours), the activation of PARP is present primarily in neuronal elements. Subsequently, (at 3 to 4 days after stroke), a second wave of PARP activation is evident, but this time it appears to localize to infiltrating immune/inflammatory cells. ${ }^{43}$

With respect to Alzheimer's disease, the activation of PARP mainly localizes to small pyramidal neurons. ${ }^{45}$ It is interesting to mention that a recent study has reported the development of circulating IgG antibodies against poly(ADP-ribose) in the serum of patients with Alzheimer's disease. ${ }^{99}$ Most likely the background of this phenomenon is that PARP activation, followed by necrosis and the release of cellular content into the extracellular space, makes poly(ADP-ribose) or poly(ADP-ribosylated) proteins immunogenic. It is also interesting to note that in a polymorphism study involving Spanish Alzheimer's disease patients and healthy controls, certain PARP-1 haplotypes were associated with an increased risk for Alzheimer's disease. ${ }^{100}$

Multiple studies demonstrate increases in poly(ADPribose), a marker of PARP activation in the dopaminergic neurons of the substantia nigra in Parkinson disease. ${ }^{46}$ In multiple sclerosis, a primate model indicates that PARP activation is increased in the affected zones, ${ }^{101}$ but no human data have yet been published on this subject. In amyotrophic lateral sclerosis, it appears that not only the overall activity but also the expression of PARP-1 is increased in the central nervous system. ${ }^{47,48} \mathrm{~A}$ similar phenomenon pertains to human posttraumatic brain injury, where both the activity and the expression of PARP-1 have been reported to increase. ${ }^{102}$ Multiple lines of recent evidence also suggests that increased peroxynitrite formation and PARP activation play a key role in the pathogenesis of diabetic neuropathy both in experimental models ${ }^{6,14,62,63}$ and in clinical disease. ${ }^{103}$

\section{Peroxynitrite Formation and PARP Activation in Human Vascular Diseases}

Accumulating evidence suggests that the endothelial dysfunction in diabetes, hypertension, atherosclerosis, shock, and heart failure is related to the local formation of reactive oxygen and nitrogen species in the vicinity of the vascular endothelium and PARP activation. ${ }^{6}$ Peroxynitrite may contribute to the vascular dysfunction by various complex interrelated mechanisms, ${ }^{6}$ which may involve endothelial glycocalyx disruption, up-regulation of adhesion molecules in endothelial cells, enhancement of neutrophil adhesion, inhibition of voltage-gated $\mathrm{K}^{+} \mathrm{K}(\mathrm{v})$ and $\mathrm{Ca}^{2+}$-activated $\mathrm{K}^{+}$channels in coronary arterioles and vascular prostacyclin synthase, and apoptosis and/or PARP-dependent cell death in endothelial and vascular smooth muscle cells, ${ }^{6}$ among many others.

Several lines of evidence support the pathogenetic role of endogenous peroxynitrite formation in diabetic cardiovascular complications in humans ${ }^{6,12,63}$ : 1) increased nitrotyrosine levels are detectable in plasma and platelets of diabetic patients ${ }^{6}$; 2) hyperglycemia induces increased nitrotyrosine formation in human endothelial cells ${ }^{6}$ and in diabetic patients during a period of postprandial hyperglycemia ${ }^{54,55}$; and 3 ) the degree of cell death and/or dysfunction correlates with levels of nitrotyrosine in endothelial cells, cardiomyocytes, and fibroblasts from myocardial biopsies of diabetic patients, ${ }^{56}$ and the nitrotyrosine immunoreactivity is increased in the microvasculature of type 2 diabetic patients and correlates with fasting blood glucose, $\mathrm{HbA} 1 \mathrm{c}$, intracellular adhesion molecule, vascular cellular adhesion molecule, and endothelial dysfunction. ${ }^{57}$

In accordance with the multiple lines of data from blood vessels from experimental animals supporting the role of PARP in the pathogenesis of diabetic vascular dysfunction, ${ }^{13}$ there is significant direct experimental evidence showing the role of PARP activation. In a study focusing on the human diabetic microvasculature, we have compared a control group of healthy patients, a group of healthy individuals with parental history of type 2 diabetes, a group of patients with impaired glucose tolerance, and a group of type 2 diabetic patients. ${ }^{57}$ Two 2-mm forearm skin biopsies were taken from each participant and used for measurements. The percentage of PARP-positive endothelial nuclei was higher in the group with parental history of type 2 diabetes and diabetic patients compared with the controls, positively correlating with endothelial dysfunction. ${ }^{57}$ These data clearly demonstrate that PARP activation is present in healthy patients at risk of developing diabetes as well as in established type 2 diabetic patients and is associated with impairments in the vascular reactivity in the skin microcirculation (whereas no such association was noted between the loss of vascular reactivity and any of the other diabetic markers studied). ${ }^{57}$

Vascular PARP activation in diabetes may be a contributor to the impaired cellular energetic status, as shown in a study in human diabetic patients with and without neuropathy. ${ }^{104}$ In a follow-up study, it was noted that a 12-week treatment with the angiotensin-II receptor blocker valsartan improved the microvascular function of type 2 diabetic patients, and this effect was associated with a reduction in the microvascular PARP activity of these patients. ${ }^{65}$ These findings are in agreement with previous preclinical data demonstrating that angiotensin II is a potent activator of the PARP pathway via stimulation of intracellular reactive species formation in vitro and in vivo. ${ }^{18}$ It appears that PARP activation (as well as the expression of PARP) also increases in peripheral blood lymphocytes in type II diabetes, ${ }^{66}$ most likely attributable to increased oxidative stress in the vicinity of the blood vessels causing DNA strand breakage and PARP activation in circulating nucleated cells.

Vascular hyporeactivity (ie, the loss of the blood vessel to contract in response to vasoconstrictor agents), which is a characteristic feature of septic and hemorrhagic shock, is accompanied by increased nitrotyrosine formation and PARP activation, which can be ameliorated by peroxynitrite scavengers and PARP inhibitors. ${ }^{1,2,6}$ Peroxynitrite may also modulate vascular contractility in circulatory shock by altering catecholamine receptor 
signaling. ${ }^{6}$ Although there is a multitude of studies demonstrating the importance of the PARP pathway in the development of vascular dysfunction and proinflammatory vascular alterations in human endothelial cells in culture, ${ }^{1}$ the experimental evidence for the role of the PARP pathway in circulatory shock as well as various forms of other human vascular diseases is relatively scarce. One study reported that septic serum depresses the viability and the mitochondrial respiration of endothelial cells in culture ex vivo, an effect that was prevented by a pharmacological inhibitor of PARP. ${ }^{105}$ If such mechanisms are also operative in vivo, they may be responsible for a PARP-dependent vascular hyporeactivity phenomenon in sepsis.

Compelling evidence derived from preclinical studies has emerged supporting the importance of endogenous peroxynitrite formation and protein nitration in the pathogenesis of arterial hypertension. ${ }^{6,106}$ Increased cell death and NT formation were reported in human hearts of diabetic and hypertensive patients, ${ }^{56}$ and in kidney-transplanted patients with cyclosporine-induced hypertension, carvediol increased plasma antioxidant power and reduced 3-NT and transforming growth factor- $\beta$ mRNA levels. ${ }^{58}$ Furthermore, plasma nitrotyrosine and 8-isoprostane levels are significantly higher in the hypertensive patients than in normotensive controls. ${ }^{59,60}$ The role of the PARP pathway in human hypertension has not yet been investigated, although animal data support the view that it plays a pathogenetic role. ${ }^{18,107}$

Numerous studies have demonstrated increased 3-nitrotyrosine and iNOS expression in human atherosclerotic tissue ${ }^{6}$ correlating with plaque instability in patients supporting the pathogenetic role of peroxynitrite in atherosclerosis. ${ }^{6}$ Reactive oxygen and nitrogen speciesPARP-1 pathway also plays an important role in the pathogenesis of restenosis after vascular injury. ${ }^{6}$ Several studies have demonstrated increased 3-nitrotyosine immunoreactivity and/or iNOS overexpression in media and neointima after balloon injury (a model of restenosis ${ }^{6}$ ), and increased 3-nitrotyosine/tyrosine ratio in the serum of patients after stent implantation. ${ }^{61}$ The serum 3-nitrotyrosine/tyrosine ratio appears to be an independent predictor of angiographic late lumen loss in patients. ${ }^{61}$ There is also experimental evidence for the up-regulation and activation of the PARP pathway in human atherosclerotic plaques. ${ }^{64}$

Numerous experimental studies have also found increased cardiovascular peroxynitrite formation-PARP activation and have demonstrated beneficial effects of peroxynitrite scavengers and/or PARP inhibitors on cardiovascular functional impairments associated with aging or heart failure, supporting the concept that this pathway plays and important role in cardiovascular pathology. ${ }^{6,16,18}$ There are currently no published data on the activation of PARP in blood vessels from humans with aging or cardiac failure.

\section{Peroxynitrite Formation and PARP Activation in Other Human Tissues and Diseases}

There are multiple lines of strong preclinical data implicating a pathogenetic role of endogenous peroxynitrite formation and PARP activation in the development and progression of primary diabetes, reperfusion injury of liver, kidney, and other organs, as well as inflammatory disorders of the gastrointestinal tract, asthma, and acute lung disorders. ${ }^{1,5,6}$ Nevertheless, only a very limited number of clinical studies have investigated the associative (but not the possible causative) role of PARP in inflammation, and they tend to focus on rheumatoid arthritis (Table 1). The oldest body of literature focuses on antibodies against PARP in the serum of patients with autoimmune diseases. Such antibodies were demonstrated in patients with rheumatoid arthritis, systemic lupus erythematosus, systemic sclerosis, and Sjögren's syndrome, ${ }^{49-52}$ as well as ulcerative colitis and Crohn's disease. ${ }^{53}$ It is possible that these antibodies are emerging because the metabolism of the poly(ADP-ribose) is markedly decreased, as demonstrated in lymphocytes from patients with SLE. ${ }^{108}$ Whether these complexes play any role in the pathogenesis of the disease, or whether they can be used as markers or indicators of disease severity remains to be determined.

More recent studies have investigated the possible role of PARP polymorphisms in the pathogenesis of various inflammatory diseases. A study involving a population of Spanish patients with rheumatoid arthritis identified two unique PARP-1 haplotypes that may play a role in susceptibility to the disease. ${ }^{109} \mathrm{~A}$ study in Korean patients has unveiled that certain polymorphisms in PARP are significantly associated with nephritis and arthritis in systemic lupus erythematosus patients. ${ }^{110}$ Additional disease conditions in which PARP activation has been directly demonstrated in humans include chronic obstructive pulmonary disease, with peripheral blood lymphocytes showing signs of PARP activation, ${ }^{74}$ ulcerative colitis (A. Keshavarzian, Z. Zsengeller, C. Szabo, unpublished observations), and kidney transplantation, in which higher expression of PARP-1 in transplanted kidneys is associated with a worsening of allograft renal function. ${ }^{67,68}$

\section{Perspectives}

Throughout the last 2 decades, the field of peroxynitrite has emerged, and the field of PARP has undergone a number of important directional changes. In 1990 peroxynitrite was described as an interesting biochemical intermediate of $\mathrm{NO}$ and superoxide, ${ }^{111}$ with the potential of being an endogenous cytotoxin. Throughout the last 18 years, the cytotoxic effects of the molecule have been confirmed in multiple disease conditions, and, as shown in the current review, the evidence for its role in human disease has accumulated. Currently, major research efforts in the field of peroxynitrite continue to focus on better understanding the molecular mechanisms of this species in triggering cell death (apoptosis, necrosis) as well as inflammatory mediator production. In addition, multiple approaches have been initiated to therapeutically neutralize this species, with hope for improved treatment of neurodegenerative, cardiovascular, and inflammatory diseases. ${ }^{5,6}$ The research field of PARP has also undergone many directional changes. The early focus of 
the research work implicating PARP in DNA repair, and PARP cleavage as a marker/potential effector of apoptosis has shifted in the mid 1990s to focus on the phenomenon of PARP activation, as an active process in the pathogenesis of various diseases. ${ }^{78,112}$ In the late 1990s, the exact role of PARP in regulating cell death has been clarified, and PARP emerged as an active contributor to cell necrosis (a process previously characterized as futile and unregulated). ${ }^{113}$ Additional work has focused on the role of PARP in signal transduction and gene expression processes, ${ }^{2,4,114-117}$ as well as a re-emergence of PARP in DNA repair, and efforts to exploit this role of the enzyme as an adjunct therapeutic agent to cancer chemotherapy ${ }^{88-91}$ From 2005, several ultrapotent PARP inhibitors have entered the clinical stage of testing, both for malignancies as well as for cardiovascular diseases. The clinical testing of PARP inhibitors is expected to produce additional, direct human evidence for the role of this enzyme in various diseases. In parallel with the clinical efforts, exciting recent developments in basic research have provided evidence for unexpected endogenous factors in the regulation of PARP, ranging from xanthines and vitamins to female sex hormones, rendering the regulation of PARP a much more dynamic and organic process than previously thought. ${ }^{8}$ PARP may also play previously unrecognized roles in physiological processes, including memory formation ${ }^{118,119}$ and angiogenesis, ${ }^{120-123}$ findings that will present interesting new challenges both for basic research as well as clinical exploitation of PARP inhibitors. In addition, the mechanisms whereby PARP activation contributes to cell injury are constantly being expanded and revised, with recent studies providing evidence for an interplay between PARP and the mitochondrial death factor AIF (apoptosis-inducing factor), ${ }^{124}$ with evidence for a direct cytotoxic effect of the endogenously produced poly(ADP-ribose) polymer, ${ }^{125}$ as well as by progress in mechanistically defining the nuclear interactions of PARP in the regulation of gene expression. ${ }^{126,127}$ There is also increasing interest in studying the role of poly(ADP-ribose) metabolism and minor isoforms of PARP family. . $^{128-130}$ We can expect that the up-coming decade will produce both interesting mechanistic basic research advances in the field of peroxynitrite and PARP, as well as further progress in the therapeutic translation of the experimental observations at the bedside. We can also expect that one question that is being continuously speculated on (whether chronic PARP inhibition can be an acceptable therapeutic strategy, in light of the role of the enzyme in DNA repair) (as discussed in Graziani and $\mathrm{Szabo}^{88}$ ) will be addressed by direct experimental means.

\section{Clinical Implications}

In the current review, we have presented a large body of direct human experimental evidence supporting the view that reactive nitrogen species generation (including, not exclusively, peroxynitrite) and activation of the nuclear enzyme PARP contribute to the pathogenesis of various human diseases. Taking the clinical data together with the body of preclinical data as a whole, one can surmise that pharmacological inhibition of PARP may provide significant benefits in multiple disease conditions by salvaging cardiomyocytes, endothelial cells, and neurons, by reducing the degree of inflammation, and by improving the function of various organs afflicted by diseases that induce the generation of reactive oxygen and nitrogen species. As is often the case with human studies, the relatively low availability of human tissue materials and the limited availability of clinical-stage PARP inhibitors are likely to represent the most important bottlenecks in the generation of additional human data. As the data stand now, the most available human data relate to various forms of heart diseases, various forms of acute and chronic central nervous system diseases, and diabetic vascular complications. As additional PARP inhibitors enter clinical stage testing, one can hope that the body of direct human clinical and mechanistic data on the pathogenetic role of PARP will increase. Also, as recent data demonstrate that PARP is regulated by a multitude of physiological factors-which now include, among others, sex hormones, the active form of vitamin D, caffeine derivatives, as well as many other molecules (Figure 2) ${ }^{8}$ - one can expect that correlational human studies will be initiated to test the role of these factors in the regulation of PARP in human health and disease.

\section{References}

1. Virág L, Szabo C: The therapeutic potential of poly(ADP-ribose) polymerase inhibitors. Pharmacol Rev 2002, 54:375-429

2. Jagtap P, Szabo C: Poly(ADP-ribose) polymerase and the therapeutic effects of its inhibitors. Nat Rev Drug Discov 2005, 4:421-440

3. Schreiber V, Dantzer F, Ame JC, de Murcia G: Poly(ADP-ribose): novel functions for an old molecule. Nat Rev Mol Cell Biol 2006, 7:517-528

4. Hassa PO, Hottiger MO: The diverse biological roles of mammalian PARPS, a small but powerful family of poly-ADP-ribose polymerases. Front Biosci 2008, 13:3046-3082

5. Szabó C, Ischiropoulos H, Radi R: Peroxynitrite: biochemistry, pathophysiology and development of therapeutics. Nat Rev Drug Discov 2007, 6:662-680

6. Pacher P, Beckman JS, Liaudet L: Nitric oxide and peroxynitrite in health and disease. Physiol Rev 2007, 87:315-424

7. Szabo C: Multiple pathways of peroxynitrite cytotoxicity. Toxicol Lett 2003, 140-141:105-112

8. Szabo C, Pacher P, Swanson RA: Novel modulators of poly(ADPribose) polymerase. Trends Pharmacol Sci 2006, 27:626-630

9. Aguilar-Quesada R, Munoz-Gamez JA, Martin-Oliva D, Peralta-Leal A, Quiles-Perez R, Rodriguez-Vargas JM, de Almodovar MR, Conde C, Ruiz-Extremera A, Oliver FJ: Modulation of transcription by PARP-1: consequences in carcinogenesis and inflammation. Curr Med Chem 2007, 14:1179-1187

10. Chiarugi A: Poly(ADP-ribosyl)ation and stroke. Pharmacol Res 2005 52:15-24

11. Komjáti K, Besson VC, Szabo C: Poly(ADP-ribose) polymerase inhibitors as potential therapeutic agents in stroke and neurotrauma Curr Drug Targets CNS Neurol Disord 2005, 4:179-194

12. Pacher P, Schulz R, Liaudet L, Szabo C: Nitrosative stress and pharmacological modulation of heart failure. Trends Pharmacol Sci 2005, 26:302-310

13. Pacher P, Szabo C: Role of poly(ADP-ribose) polymerase-1 activation in the pathogenesis of diabetic complications: endothelial dysfunction, as a common underlying theme. Antioxid Redox Signal 2005, 7:1568-1580

14. Obrosova IG, Julius UA: Role for poly(ADP-ribose) polymerase ac- 
tivation in diabetic nephropathy, neuropathy and retinopathy. Curr Vasc Pharmacol 2005, 3:267-283

15. Evgenov OV, Liaudet L: Role of nitrosative stress and activation of poly(ADP-ribose) polymerase-1 in cardiovascular failure associated with septic and hemorrhagic shock. Curr Vasc Pharmacol 2005, 3:293-299

16. Csiszar A, Pacher P, Kaley G, Ungvari Z: Role of oxidative and nitrosative stress, longevity genes and poly(ADP-ribose) polymerase in cardiovascular dysfunction associated with aging. Curr Vasc Pharmacol 2005, 3:285-291

17. Kauppinen TM, Swanson RA: The role of poly(ADP-ribose) polymerase-1 in CNS disease. Neuroscience 2007, 145:1267-1272

18. Pacher P, Szabo C: Role of poly(ADP-ribose) polymerase 1 (PARP-1) in cardiovascular diseases: the therapeutic potential of PARP inhibitors. Cardiovasc Drug Rev 2007, 25:235-260

19. Hayashi Y, Sawa Y, Ohtake S, Fukuyama N, Nakazawa H, Matsuda $\mathrm{H}$ : Peroxynitrite formation from human myocardium after ischemiareperfusion during open heart operation. Ann Thorac Surg 2001, 72 571-576

20. Hayashi $Y$, Sawa $Y$, Fukuyama N, Miyamoto $Y$, Takahashi $T$, Nakazawa H, Matsuda H: Leukocyte-depleted terminal blood cardioplegia provides superior myocardial protective effects in association with myocardium-derived nitric oxide and peroxynitrite production for patients undergoing prolonged aortic crossclamping for more than 120 minutes. J Thorac Cardiovasc Surg 2003, 126:1813-1821

21. Mehlhorn U, Krahwinkel A, Geissler HJ, LaRosee K, Fischer UM, Klass O, Suedkamp M, Hekmat K, Tossios P, Bloch W: Nitrotyrosine and 8-isoprostane formation indicate free radical-mediated injury in hearts of patients subjected to cardioplegia. J Thorac Cardiovasc Surg 2003, 125:178-183

22. Baker CS, Dutka DP, Pagano D, Rimoldi O, Pitt M, Hall RJ, Polak JM, Bonser RS, Camici PG: Immunocytochemical evidence for inducible nitric oxide synthase and cyclooxygenase-2 expression with nitrotyrosine formation in human hibernating myocardium. Basic Res Cardiol 2002, 97:409-415

23. Szabolcs MJ, Ravalli S, Minanov O, Sciacca RR, Michler RE, Cannon PJ: Apoptosis and increased expression of inducible nitric oxide synthase in human allograft rejection. Transplantation 1998, 65:804-812

24. Ravalli S, Albala A, Ming M, Szabolcs M, Barbone A, Michler RE, Cannon PJ: Inducible nitric oxide synthase expression in smooth muscle cells and macrophages of human transplant coronary artery disease. Circulation 1998, 97:2338-2345

25. Wildhirt SM, Weis M, Schulze C, Conrad N, Pehlivanli S, Rieder G, Enders G, von Scheidt W, Reichart B: Expression of endomyocardial nitric oxide synthase and coronary endothelial function in human cardiac allografts. Circulation 2001, 104:I336-I343

26. Nicholls SJ, Wang Z, Koeth R, Levison B, DelFraino B, Dzavik V, Griffith OW, Hathaway D, Panza JA, Nissen SE, Hochman JS, Hazen SL: Metabolic profiling of arginine and nitric oxide pathways predicts hemodynamic abnormalities and mortality in patients with cardiogenic shock after acute myocardial infarction. Circulation 2007, 116:2315-2324

27. Tóth-Zsámboki E, Horvath E, Vargova K, Pankotai E, Murthy $K_{\text {, }}$ Zsengeller Z, Barany T, Pek T, Fekete K, Kiss RG, Preda I, Lacza Z, Gero D, Szabo C: Activation of poly(ADP-ribose) polymerase by myocardial ischemia and coronary reperfusion in human circulating leukocytes. Mol Med 2006, 12:221-228

28. Yao L, Huang K, Huang D, Wang J, Guo H, Liao Y: Acute myocardial infarction induced increases in plasma tumor necrosis factor-alpha and interleukin-10 are associated with the activation of poly(ADPribose) polymerase of circulating mononuclear cell. Int $\mathrm{J}$ Cardiol 2008, 123:366-368

29. Kooy NW, Lewis SJ, Royall JA, Ye YZ, Kelly DR, Beckman JS: Extensive tyrosine nitration in human myocardial inflammation: evidence for the presence of peroxynitrite. Crit Care Med 1997, 25:812-819

30. Chaves AA, Mihm MJ, Schanbacher BL, Basuray A, Liu C, Ayers LW, Bauer JA: Cardiomyopathy in a murine model of AIDS: evidence of reactive nitrogen species and corroboration in human HIV/AIDS cardiac tissues. Cardiovasc Res 2003, 60:108-118

31. Soriano FG, Nogueira AC, Caldini EG, Lins MH, Teixeira AC, Cappi SB, Lotufo PA, Bernik MM, Zsengeller Z, Chen M, Szabo C: Potential role of poly(adenosine 5'-diphosphate-ribose) polymerase activation in the pathogenesis of myocardial contractile dysfunction associated with human septic shock. Crit Care Med 2006, 34:1073-1079

32. Vanderheyden M, Bartunek J, Knaapen M, Kockx M, De Bruyne B, Goethals M: Hemodynamic effects of inducible nitric oxide synthase and nitrotyrosine generation in heart failure. J Heart Lung Transplant 2004, 23:723-728

33. Lokuta AJ, Maertz NA, Meethal SV, Potter KT, Kamp TJ, Valdivia HH Haworth RA: Increased nitration of sarcoplasmic reticulum $\mathrm{Ca} 2+$ ATPase in human heart failure. Circulation 2005, 111:988-995

34. Borbély A, Toth A, Edes I, Virag L, Papp JG, Varro A, Paulus WJ, van der Velden J, Stienen GJ, Papp Z: Peroxynitrite-induced alphaactinin nitration and contractile alterations in isolated human myocardial cells. Cardiovasc Res 2005, 67:225-233

35. de Jonge N, van Wichen DF, van Kuik J, Kirkels H, Lahpor JR, Gmelig-Meyling FH, van den Tweel JG, de Weger RA: Cardiomyocyte death in patients with end-stage heart failure before and after support with a left ventricular assist device: low incidence of apoptosis despite ubiquitous mediators. J Heart Lung Transplant 2003, 22:1028-1036

36. Pillai JB, Russell HM, Raman J, Jeevanandam V, Gupta MP: Increased expression of poly(ADP-ribose) polymerase- 1 contributes to caspase-independent myocyte cell death during heart failure. Am J Physiol 2005, 288:H486-H496

37. Pillai JB, Isbatan A, Imai S, Gupta MP: Poly(ADP-ribose) polymerase-1-dependent cardiac myocyte cell death during heart failure is mediated by NAD + depletion and reduced Sir2alpha deacetylase activity. J Biol Chem 2005, 280:43121-43130

38. Molnár A, Toth A, Bagi Z, Papp Z, Edes I, Vaszily M, Galajda Z, Papp JG, Varro A, Szuts V, Lacza Z, Gero D, Szabo C: Activation of the poly(ADP-ribose) polymerase pathway in human heart failure. Mol Med 2006, 12:143-152

39. Groenendaal F, Lammers H, Smit D, Nikkels PG: Nitrotyrosine in brain tissue of neonates after perinatal asphyxia. Arch Dis Child Fetal Neonatal Ed 2006, 91:F429-F433

40. Taffi R, Nanetti L, Mazzanti L, Bartolini M, Vignini A, Raffaelli F, Pasqualetti P, Vernieri F, Provinciali L, Silvestrini M: Plasma levels of nitric oxide and stroke outcome. J Neurol 2008,255:94-98

41. Nanetti L, Taffi R, Vignini A, Moroni C, Raffaelli F, Bacchetti T, Silvestrini M, Provinciali L, Mazzanti L: Reactive oxygen species plasmatic levels in ischemic stroke. Mol Cell Biochem 2007 303:19-25

42. Love S, Barber R, Wilcock GK: Neuronal accumulation of poly(ADPribose) after brain ischaemia. Neuropathol Appl Neurobiol 1999 25:98-103

43. Love S, Barber R, Wilcock GK: Neuronal death in brain infarcts in man. Neuropathol Appl Neurobiol 2000, 26:55-66

44. Ischiropoulos $\mathrm{H}$, Beckman JS: Oxidative stress and nitration in neurodegeneration: cause, effect, or association? J Clin Invest 2003 111:163-169

45. Love S, Barber R, Wilcock GK: Increased poly(ADP-ribosyl)ation of nuclear proteins in Alzheimer's disease. Brain 1999, 122:247-253

46. Soos J, Engelhardt JI, Siklos L, Havas L, Majtenyi K: The expression of PARP. NF-kappa B and parvalbumin is increased in Parkinson disease. Neuroreport 2004, 15:1715-1718

47. Kim SH, Henkel JS, Beers DR, Sengun IS, Simpson EP, Goodman JC, Engelhardt JI, Siklos L, Appel SH: PARP expression is increased in astrocytes but decreased in motor neurons in the spinal cord of sporadic ALS patients. J Neuropathol Exp Neurol 2003, 62:88-103

48. Kim SH, Engelhardt JI, Henkel JS, Siklos L, Soos J, Goodman C Appel SH: Widespread increased expression of the DNA repair enzyme PARP in brain in ALS. Neurology 2004, 62:319-322

49. Okolie EE, Shall S: The significance of antibodies to poly(adenosine diphosphate-ribose) in systemic lupus erythematosus. Clin Exp Immunol 1979, 36:151-164

50. Negri C, Scovassi Al, Cerino A, Negroni M, Borzi RM, Meliconi R, Facchini A, Montecucco CM, Astaldi Ricotti GC: Autoantibodies to poly(ADP-ribose)polymerase in autoimmune diseases. Autoimmunity 1990, 6:203-209

51. Rosen A, Casciola-Rosen L: Altered autoantigen structure in Sjogren's syndrome: implications for the pathogenesis of autoimmune tissue damage. Crit Rev Oral Biol Med 2004, 15:156-164

52. Jeoung D, Lim Y, Lee EB, Lee S, Kim HY, Lee H, Song YW: Identification of autoantibody against poly (ADP-ribose) polymerase 
(PARP) fragment as a serological marker in systemic lupus erythematosus. J Autoimmun 2004, 22:87-94

53. Reumaux D, Meziere C, Colombel JF, Duthilleul P, Mueller S: Distinct production of autoantibodies to nuclear components in ulcerative colitis and in Crohn's disease. Clin Immunol Immunopathol 1995, 77:349-357

54. Ceriello A, Mercuri F, Quagliaro L, Assaloni R, Motz E, Tonutti L, Taboga C: Detection of nitrotyrosine in the diabetic plasma: evidence of oxidative stress. Diabetologia 2001, 44:834-838

55. Ceriello A, Quagliaro L, Catone B, Pascon R, Piazzola M, Bais B, Marra G, Tonutti L, Taboga C, Motz E: Role of hyperglycemia in nitrotyrosine postprandial generation. Diabetes Care 2002, 25: $1439-1443$

56. Frustaci A, Kajstura J, Chimenti C, Jakoniuk I, Leri A, Maseri A, Nadal-Ginard B, Anversa P: Myocardial cell death in human diabetes. Circ Res 2000, 87:1123-1132

57. Szabó C, Zanchi A, Komjati K, Pacher P, Krolewski AS, Quist WC, LoGerfo FW, Horton ES, Veves A: Poly(ADP-ribose) polymerase is activated in subjects at risk of developing type 2 diabetes and is associated with impaired vascular reactivity. Circulation 2002, 106:2680-2686

58. Calo L, Giacon B, Davis PA, Pagnin E, Piccin A, Riegler P, Huber W, Antonello A, Semplicini A: Oxidative stress and TGFbeta in kidneytransplanted patients with cyclosporin-induced hypertension. Effect of carvedilol and nifedipine. Clin Nephrol 2002, 58:103-110

59. Ohta M, Nanri H, Matsushima Y, Sato Y, Ikeda M: Blood pressurelowering effects of lifestyle modification: possible involvement of nitric oxide bioavailability. Hypertens Res 2005, 28:779-786

60. Zhou L, Xiang W, Potts J, Floyd M, Sharan C, Yang H, Ross J, Nyanda AM, Guo Z: Reduction in extracellular superoxide dismutase activity in African-American patients with hypertension. Free Radic Biol Med 2006, 41:1384-1391

61. Inoue T, Kato T, Hikichi Y, Hashimoto S, Hirase T, Morooka T, Imoto Y, Takeda Y, Sendo F, Node K: Stent-induced neutrophil activation is associated with an oxidative burst in the inflammatory process, leading to neointimal thickening. Thromb Haemost 2006, 95:43-48

62. Pacher P, Obrosova IG, Mabley JG, Szabo C: Role of nitrosative stress and peroxynitrite in the pathogenesis of diabetic complications. Emerging new therapeutical strategies. Curr Med Chem 2005, 12:267-275

63. Pacher P, Szabo C: Role of peroxynitrite in the pathogenesis of cardiovascular complications of diabetes. Curr Opin Pharmacol 2006, 6:136-141

64. Martinet W, Knaapen MW, De Meyer GR, Herman AG, Kockx MM: Elevated levels of oxidative DNA damage and DNA repair enzymes in human atherosclerotic plaques. Circulation 2002, 106:927-932

65. Shrikhande G, Khaodhiar L, Scali S, Lima C, Hubbard M, Dudley K, Ganda O, Ferran C, Veves A: Valsartan improves resting skin blood flow in type 2 diabetic patients and reduces poly(adenosine diphosphate-ribose) polymerase activation. J Vasc Surg 2006, 43:760-770

66. Adaikalakoteswari A, Rema M, Mohan V, Balasubramanyam M: Oxidative DNA damage and augmentation of poly(ADP-ribose) polymerase/nuclear factor-kappa B signaling in patients with type 2 diabetes and microangiopathy. Int J Biochem Cell Biol 2007, 39:1673-1684

67. O'Valle F, Benitez MC, Gomez-Morales M, Bravo J, Osuna A, MartinOliva D, Oliver FJ, Del Moral RG: Role of poly (ADP-ribose) polymerase in kidney transplant and its relationship with delayed renal function: multivariate analysis. Transplant Proc 2005, 37:3684-3687

68. O'Valle F, Gomez-Morales M, Del Moral RM, Seron D, Moreso F, Osuna A, Oliver FJ, Del Moral RG: Poly(ADP-ribose) polymerase expression in kidney transplantation: from alfa (alpha) to omega (omega). Transplant Proc 2007, 39:2099-2101

69. Lamb NJ, Gutteridge JM, Baker C, Evans TW, Quinlan GJ: Oxidative damage to proteins of bronchoalveolar lavage fluid in patients with acute respiratory distress syndrome: evidence for neutrophil-mediated hydroxylation, nitration, and chlorination. Crit Care Med 1999, 27:1738-1744

70. Lamb NJ, Quinlan GJ, Westerman ST, Gutteridge JM, Evans TW: Nitration of proteins in bronchoalveolar lavage fluid from patients with acute respiratory distress syndrome receiving inhaled nitric oxide. Am J Respir Crit Care Med 1999, 160:1031-1034

71. Zhu S, Ware LB, Geiser T, Matthay MA, Matalon S: Increased levels of nitrate and surfactant protein a nitration in the pulmonary edema fluid of patients with acute lung injury. Am J Respir Crit Care Med 2001, 163:166-172

72. Thomson L, Christie J, Vadseth C, Lanken PN, Fu X, Hazen SL, Ischiropoulos $\mathrm{H}$ : Identification of immunoglobulins that recognize 3-nitrotyrosine in patients with acute lung injury after major trauma. Am J Respir Cell Mol Biol 2007, 36:152-157

73. Shimizu K, Ogawa F, Muroi E, Hara T, Komura K, Bae SJ, Sato S: Increased serum levels of nitrotyrosine, a marker for peroxynitrite production, in systemic sclerosis. Clin Exp Rheumatol 2007, 25:281-286

74. Hageman GJ, Larik I, Pennings HJ, Haenen GR, Wouters EF, Bast A: Systemic poly(ADP-ribose) polymerase-1 activation, chronic inflammation, and oxidative stress in COPD patients. Free Radic Biol Med 2003, 35:140-148

75. Szabó C, Dawson VL: Role of poly(ADP-ribose) synthetase in inflammation and ischaemia-reperfusion. Trends Pharmacol Sci 1998, 19:287-298

76. Szabo C, Zingarelli B, O'Connor M, Salzman AL: DNA strand breakage, activation of poly (ADP-ribose) synthetase, and cellular energy depletion are involved in the cytotoxicity of macrophages and smooth muscle cells exposed to peroxynitrite. Proc Natl Acad Sc USA 1996, 93:1753-1758

77. Zingarelli B, O'Connor M, Wong H, Salzman AL, Szabo C: Peroxynitrite-mediated DNA strand breakage activates poly-adenosine diphosphate ribosyl synthetase and causes cellular energy depletion in macrophages stimulated with bacterial lipopolysaccharide. J Immunol 1996, 156:350-358

78. Szabo C, Virag L, Cuzzocrea S, Scott GS, Hake P, O'Connor MP, Zingarelli B, Salzman A, Kun E: Protection against peroxynitriteinduced fibroblast injury and arthritis development by inhibition of poly(ADP-ribose) synthase. Proc Natl Acad Sci USA 1998, 95:3867-3872

79. Salvemini D, Mazzon E, Dugo L, Riley DP, Serraino I, Caputi AP, Cuzzocrea S: Pharmacological manipulation of the inflammatory cascade by the superoxide dismutase mimetic. M40403. Br J Pharmacol 2001, 132:815-827

80. Salvemini D, Mazzon E, Dugo L, Serraino I, De Sarro A, Caputi AP Cuzzocrea S: Amelioration of joint disease in a rat model of collageninduced arthritis by M40403, a superoxide dismutase mimetic. Arthritis Rheum 2001, 44:2909-2921

81. Obrosova IG, Mabley JG, Zsengeller Z, Charniauskaya T, Abatan OI, Groves JT, Szabo C: Role for nitrosative stress in diabetic neuropathy: evidence from studies with a peroxynitrite decomposition catalyst. FASEB J 2005, 19:401-403

82. Drel VR, Pacher P, Stevens MJ, Obrosova IG: Aldose reductase inhibition counteracts nitrosative stress and poly(ADP-ribose) polymerase activation in diabetic rat kidney and high-glucose-exposed human mesangial cells. Free Radic Biol Med 2006, 40:1454-1465

83. Drel VR, Pacher P, Vareniuk I, Pavlov IA, Inytska O, Lyzogubov VV, Bell SR, Groves JT, Obrosova IG: Evaluation of the peroxynitrite decomposition catalyst $\mathrm{Fe}(\mathrm{III})$ tetra-mesitylporphyrin octasulfonate on peripheral neuropathy in a mouse model of type 1 diabetes. Int $J$ Mol Med 2007, 20:783-792

84. Pieper GM, Nilakantan V, Chen M, Zhou J, Khanna AK, Henderson JD Jr, Johnson CP, Roza AM, Szabo C: Protective mechanisms of a metalloporphyrinic peroxynitrite decomposition catalyst. WW85, in rat cardiac transplants. J Pharmacol Exp Ther 2005, 314:53-60

85. Scott GS, Cuzzocrea S, Genovese T, Koprowski H, Hooper DC: Uric acid protects against secondary damage after spinal cord injury. Proc Natl Acad Sci USA 2005, 102:3483-3488

86. Genovese T, Mazzon E, Esposito E, Muia C, Di Paola R, Bramanti P, Cuzzocrea S: Beneficial effects of FeTSPP, a peroxynitrite decomposition catalyst, in a mouse model of spinal cord injury. Free Radic Biol Med 2007, 43:763-780

87. Radovits T, Seres L, Gero D, Lin LN, Beller CJ, Chen SH, Zotkina J, Berger I, Groves JT, Szabo C, Szabo G: The peroxynitrite decomposition catalyst FP15 improves ageing-associated cardiac and vascular dysfunction. Mech Ageing Dev 2007, 128:173-181

88. Graziani G, Szabo C: Clinical perspectives of PARP inhibitors. Pharmacol Res 2005, 52:109-118

89. Zaremba T, Curtin NJ: PARP inhibitor development for systemic cancer targeting. Anticancer Agents Med Chem 2007, 7:515-523

90. Lewis C, Low JA: Clinical poly(ADP-ribose) polymerase inhibitors for 
the treatment of cancer. Curr Opin Investig Drugs 2007, 8:10511056

91. O'Connor MJ, Martin NM, Smith GC: Targeted cancer therapies based on the inhibition of DNA strand break repair. Oncogene 2007, 26:7816-7824

92. Ferdinandy P, Schulz R: Nitric oxide, superoxide, and peroxynitrite in myocardial ischaemia-reperfusion injury and preconditioning. $\mathrm{Br}$ J Pharmacol 2003, 138:532-543

93. Ungvári Z, Gupte SA, Recchia FA, Batkai S, Pacher P: Role of oxidative-nitrosative stress and downstream pathways in various forms of cardiomyopathy and heart failure. Curr Vasc Pharmacol 2005, 3:221-229

94. Mihm MJ, Yu F, Carnes CA, Reiser PJ, McCarthy PM, Van Wagoner DR, Bauer JA: Impaired myofibrillar energetics and oxidative injury during human atrial fibrillation. Circulation 2001, 104:174-180

95. Gero D, Szabo C: Role of the peroxynitrite-poly (ADP-ribose) polymerase pathway in the pathogenesis of liver injury. Curr Pharm Des 2006, 12:2903-2910

96. Bromme HJ, Holtz J: Apoptosis in the heart: when and why? Mol Cell Biochem 1996, 163-164:261-275

97. Ramlawi B, Feng J, Mieno S, Szabo C, Zsengeller Z, Clements R, Sodha N, Boodhwani M, Bianchi C, Sellke FW: Indices of apoptosis activation after blood cardioplegia and cardiopulmonary bypass. Circulation 2006, 114:I257-I263

98. Morrow DA, Baran K, Krakover R, Dauerman H, Murphy SA, Kumar S, McCabe CH, Brickman CM, Salzman AL: Safety, pharmacokinetics, and pharmacodynamics of a single intravenous administration of INO-1001 in subjects with ST-elevated myocardial infarction (STEMI) undergoing primary percutaneous coronary intervention: results of the TIMI 37A trial. J Am Coll Cardiol 2007, 202A

99. Kanai $Y$, Akatsu $H$, lizuka $H$, Morimoto $C$ : Could serum antibody to poly(ADP-ribose) and/or histone $\mathrm{H} 1$ be marker for senile dementia of Alzheimer type? Ann NY Acad Sci 2007, 1109:338-344

100. Infante J, Llorca J, Mateo I, Rodriguez-Rodriguez E, SanchezQuintana C, Sanchez-Juan P, Fernandez-Viadero C, Pena N, Berciano J, Combarros O: Interaction between poly(ADP-ribose) polymerase 1 and interleukin $1 \mathrm{~A}$ genes is associated with Alzheimer's disease risk. Dement Geriatr Cogn Disord 2007, 23:215-218

101. Kauppinen TM, Suh SW, Genain CP, Swanson RA: Poly(ADP-ribose) polymerase-1 activation in a primate model of multiple sclerosis. J Neurosci Res 2005, 81:190-198

102. Ang BT, Yap E, Lim J, Tan WL, Ng PY, Ng I, Yeo TT: Poly(adenosine diphosphate-ribose) polymerase expression in human traumatic brain injury. J Neurosurg 2003, 99:125-130

103. Hoeldtke RD, Bryner KD, McNeill DR, Hobbs GR, Riggs JE, Warehime SS, Christie I, Ganser G, Van Dyke K: Nitrosative stress, uric acid, and peripheral nerve function in early type 1 diabetes. Diabetes 2002, 51:2817-2825

104. Greenman RL, Panasyuk S, Wang X, Lyons TE, Dinh T, Longoria L, Giurini JM, Freeman J, Khaodhiar L, Veves A: Early changes in the skin microcirculation and muscle metabolism of the diabetic foot. Lancet 2005, 366:1711-1717

105. Boulos M, Astiz ME, Barua RS, Osman M: Impaired mitochondrial function induced by serum from septic shock patients is attenuated by inhibition of nitric oxide synthase and poly(ADP-ribose) synthase. Crit Care Med 2003, 31:353-358

106. Escobales N, Crespo MJ: Oxidative-nitrosative stress in hypertension. Curr Vasc Pharmacol 2005, 3:231-246

107. Szabó C, Pacher P, Zsengeller Z, Vaslin A, Komjati K, Benko R Chen M, Mabley JG, Kollai M: Angiotensin II-mediated endothelial dysfunction: role of poly(ADP-ribose) polymerase activation. Mol Med 2004, 10:28-35

108. Sibley JT, Haug BL, Lee JS: Altered metabolism of poly(ADP-ribose) in the peripheral blood lymphocytes of patients with systemic lupus erythematosus. Arthritis Rheum 1989, 32:1045-1049

109. Pascual M, Lopez-Nevot MA, Caliz R, Ferrer MA, Balsa A, PascualSalcedo D, Martin J: A poly(ADP-ribose) polymerase haplotype spanning the promoter region confers susceptibility to rheumatoid arthritis. Arthritis Rheum 2003, 48:638-641

110. Hur JW, Sung YK, Shin HD, Park BL, Cheong HS, Bae SC: Poly(ADPribose) polymerase (PARP) polymorphisms associated with nephritis and arthritis in systemic lupus erythematosus. Rheumatology (Oxford) 2006, 45:711-717
111. Beckman JS, Beckman TW, Chen J, Marshall PA, Freeman BA: Apparent hydroxyl radical production by peroxynitrite: implications for endothelial injury from nitric oxide and superoxide. Proc Nat Acad Sci USA 1990, 87:1620-1624

112. Zhang J, Dawson VL, Dawson TM, Snyder SH: Nitric oxide activation of poly(ADP-ribose) synthetase in neurotoxicity. Science 1994 263:687-689

113. Virág L, Scott GS, Cuzzocrea S, Marmer D, Salzman AL, Szabo C: Peroxynitrite-induced thymocyte apoptosis: the role of caspases and poly (ADP-ribose) synthetase (PARS) activation. Immunology 1998, 94:345-355

114. Ethier C, Labelle Y, Poirier GG: PARP-1-induced cell death through inhibition of the MEK/ERK pathway in MNNG-treated HeLa cells. Apoptosis 2007, 12:2037-2049

115. Alano CC, Swanson RA: Players in the PARP-1 cell-death pathway: JNK1 joins the cast. Trends Biochem Sci 2006, 31:309-311

116. Haince JF, McDonald D, Rodrigue A, Dery U, Masson JY, Hendzel MJ, Poirier GG: PARP1-dependent kinetics of recruitment of MRE11 and NBS1 proteins to multiple DNA damage sites. J Biol Chem 2008, 283:1197-1208

117. Cohen-Armon M: PARP-1 activation in the ERK signaling pathway. Trends Pharmacol Sci 2007, 28:556-560

118. Satchell MA, Zhang X, Kochanek PM, Dixon CE, Jenkins LW, Melick J, Szabo C, Clark RS: A dual role for poly-ADP-ribosylation in spatial memory acquisition after traumatic brain injury in mice involving $\mathrm{NAD}+$ depletion and ribosylation of 14-3-3gamma. J Neurochem 2003, 85:697-708

119. Cohen-Armon M, Visochek L, Katzoff A, Levitan D, Susswein AJ, Klein R, Valbrun M, Schwartz JH: Long-term memory requires polyADP-ribosylation. Science 2004, 304:1820-1822

120. Rajesh M, Mukhopadhyay P, Batkai S, Godlewski G, Hasko G, Liaudet L, Pacher P: Pharmacological inhibition of poly(ADP-ribose) polymerase inhibits angiogenesis. Biochem Biophys Res Commun 2006, 350:352-357

121. Rajesh M, Mukhopadhyay P, Godlewski G, Batkai S, Hasko G, Liaudet L, Pacher P: Poly(ADP-ribose)polymerase inhibition decreases angiogenesis. Biochem Biophys Res Commun 2006 350:1056-1062

122. Tentori L, Lacal PM, Muzi A, Dorio AS, Leonetti C, Scarsella M, Ruffini F, Xu W, Min W, Stoppacciaro A, Colarossi C, Wang ZQ, Zhang J, Graziani G: Poly(ADP-ribose) polymerase (PARP) inhibition or PARP-1 gene deletion reduces angiogenesis. Eur J Cancer 2007 43:2124-2133

123. Pyriochou A, Olah G, Deitch EA, Szabo C, Papapetropoulos A: Inhibition of angiogenesis by the poly(ADP-ribose) polymerase inhibitor PJ-34. Int J Mol Med 2008, 22:113-118

124. Hong SJ, Dawson TM, Dawson VL: Nuclear and mitochondrial conversations in cell death: PARP-1 and AIF signaling. Trends Pharmacol Sci 2004, 25:259-264

125. Yu SW, Andrabi SA, Wang H, Kim NS, Poirier GG, Dawson TM, Dawson VL: Apoptosis-inducing factor mediates poly(ADP-ribose) (PAR) polymer-induced cell death. Proc Natl Acad Sci USA 2006 103:18314-18319

126. Wacker DA, Ruhl DD, Balagamwala EH, Hope KM, Zhang T, Kraus WL: The DNA binding and catalytic domains of poly(ADP-ribose) polymerase 1 cooperate in the regulation of chromatin structure and transcription. Mol Cell Biol 2007, 27:7475-7485

127. Krishnakumar R, Gamble MJ, Frizzell KM, Berrocal JG, Kininis M, Kraus WL: Reciprocal binding of PARP-1 and histone $\mathrm{H} 1$ at promoters specifies transcriptional outcomes. Science 2008, 319:819-821

128. Gagné JP, Hendzel MJ, Droit A, Poirier GG: The expanding role of poly(ADP-ribose) metabolism: current challenges and new perspectives. Curr Opin Cell Biol 2006, 18:145-151

129. Droit A, Hunter JM, Rouleau M, Ethier C, Picard-Cloutier A, Bourgais D, Poirier GG: PARPs Database: a LIMS systems for protein-protein interaction data mining or laboratory information management system. BMC Bioinformatics 2007, 8:483

130. Rouleau M, McDonald D, Gagne P, Ouellet ME, Droit A, Hunter JM, Dutertre S, Prigent C, Hendzel MJ, Poirier GG: PARP-3 associates with polycomb group bodies and with components of the DNA damage repair machinery. J Cell Biochem 2007, 100:385-401 